Jurnal MAKSIPRENEUR, Vol. II, No. 1, Hal 59-68

\title{
BASIC LEADERSHIP TRAINING BAGI MAHASISWA DENGAN PENDEKATAN SOCIAL LEARNING THEORY
}

\section{Dian Yudhawati}

Fakultas Psikologi Universitas Teknologi Yogyakarta

\author{
Arundati Shinta \\ Fakultas Psikologi Universitas Proklamasi 45 Yogyakarta
}

\begin{abstract}
Being a good leader is a result of learning. A good leader criterion in most of people's head is either success in completing organizational tasks or beloved by most of members. That criterion is really difficult to be learned and then be internalized. Based on the social learning theory, one learns to be a leader through observation process as the first step. In daily activity, there are many leaders but only certain leader who is observed about his or her behaviors in detail. That observed leader usually success in completing organizational tasks and also beloved by his or her members. After observation, the next process is memorizing those behaviors. The next stage is trying to produce those behaviors. This third step can be achieved through leadership training. In that training, one is motivated to produce and imitate those behaviors. After training, one can practice the new leadership behaviors in daily activity if he or she receives behavior reinforcements. Because of those reinforcements, the new leadership behaviors will be his or her good habits. Actually, in that leadership training, one can learn either being a good leader or good member. Being a good member, one should be able to inspire either other members or leader. He or she should not be a problem source but a solution source.
\end{abstract}

Key words: leadership, social learning, training.

\section{PENDAHULUAN}

MenurutCovey (1997:16) kepemimpinan adalah seperti proses menanam pohon bambu. Pada mulanya bambu tidak akan nampak dari permukaan tanah, karena akarnya terlebih dahulu yang tumbuh sangat kuat. Setelah akarnya tumbuh dengan kuat, kemudian batangnya tumbuh menjulang ke langit, kokoh, dan sekaligus lentur. Deskripsi Convey (1997:16) tersebut menunjukkan bahwa seorang pemimpin tidak mungkin muncul begitu saja. Kepemimpinan harus 'ditanam' melalui berbagai proses, seperti 
halnya menanam bambu. Salah satu proses yang sering dilakukan berbagai organisasi untuk mendapatkan atau memperkuat kepemimpinan pada para karyawannya adalah melalui pelatihan (training).

Pelatihan juga dapat dilakukan di kalangan mahasiswa, karena mahasiswa kelak akan menjadi agen perubahan ke arah yang lebih positif baik di lingkungan kerja maupun di masyarakat. Oleh karena itu, pelatihan kepemimpinan di kalangan mahasiswa telah sering dilakukan oleh berbagai perguruan tinggi. Tujuannya pelatihan adalah mempersiapkan mahasiswa pada dunia kerja dan memupuk kemampuan kepemimpinan mahasiswa. Segera setelah lulus, diharapkan para sarjana baru tersebut dapat segera menjadi pemimpin yang perilakunya menjadi suri tauladan bagi lingkungan sosial dan lingkungan kerjanya.

Dalam pelatihan kepemimpinan untuk kalangan mahasiswa, materi yang disediakan sering berasal dari literatur manajemen, psikologi, dan ilmu-ilmu terapan lainnya. Selain itu materi juga berasal dari pengalaman nyata para pemimpin organisasi yang menjadi salah satu nara sumber pelatihan. Gabungan dua macam sumber materi pelatihan (literatur dan pengalaman langsung dari praktisi) adalah untuk membuat pelatihan menjadi lebih hidup, mudah dipahami, dan dapat langsung dipraktekkan di lapangan.

\section{PEMBAHASAN}

Secara umum ada tiga tipe kepemimpinan yaitu demokratis, otoriter dan laissez-faire (serba boleh, permisif) (Riyono, 2001:15). Pada tipe kepemimpinan demokratis, pemimpin selalu mengajak bawahannya bersama-sama memberikan ide untuk memecahkan masalah. Pada tipe kepemimpinan otoriter, pemimpin lebih mendahulukan ide-idenya sendiri daripada ide bawahannya. Pemimpin dianggap sebagai pihak yang paling berwenang dalam menyelesaikan suatu masalah. Pada tipe kepemimpinan laissez-faire, pemimpin digambarkan sebagai tokoh yang selalu membiarkan bawahannya menemukan sendiri pemecahan masalah yang dihadapinya. Pemimpin laissez-faire cenderung berpangku tangan saja dan segala tindakan adalah hasil karya anak buahnya.

Kenyataan yang ada di lapangan, tiga jenis pemimpin tersebut (demokratis, otoriter dan laissez-faire) sering kali diabaikan oleh para mahasiswa. Para mahasiswa cenderung hanya mengkategorikan pemimpin yang mereka temui (misalnya dosen di kelasnya) sebagai 'menyenangkan' atau 'tidak menyenangkan'. Kriteria menyenangkan atau tidak menyenangkan, kerap kali bersifat subjektif yaitu bergantung pada terpenuhi atau tidak terpenuhinya kepentingan para mahasiswa. Apabila kepentingan para mahasiswa itu terpenuhi, maka pemimpin / dosen dianggap menyenangkan. Sebaliknya, apabila kepentingan mahasiswa 
tidak terpenuhi maka pemimpin itu dikategorikan tidak menyenangkan. Fenomena ini menunjukkan bahwa para mahasiswa perlu mengetahui tentang karakteristik pemimpin yang dihadapinya.

Tujuan mengetahui karakteristik pemimpin adalah mendorong mahasiswa menjadi anak buah yang baik. Hal ini penting karena sebelum seseorang menjadi pemimpin yang baik maka ia harus menjadi anak buah yang baik terlebih dahulu (Iskan dalam TimAndriwongso, 2012:1). Anak buah yang baik berarti ia harus patuh namun tetap mempunyai pendapat yang kritis terhadap perintah pimpinannya. Pendeknya, anak buah yang baik adalah anggota organisasi yang tidak pernah menjadi sumber masalah bagi pemimpinnya bahkan justru menjadi sumber pemecahan masalah. Setelah berpengalaman menjadi anak buah yang baik, maka ia kelak akan mampu menjadi pemimpin yang baik pula. Hal ini karena ia sudah mengetahui bagaimana rasanya menjadi anak buah. Jadi pemahaman tentang karakteristik pemimpin sebenarnya akan mempersiapkan seseorang kelak menjadi pemimpin.

Cara yang paling efektif baik menjadi pemimpin maupun anak buah yang baik adalah dengan mengamati perilaku pemimpin. Pengamatan itu merupakan tahap pertama dari social learning atau belajar sosial (Bussey \& Bandura, 1999:680). Tahap selanjutnya dari social learning adalah mengingat-ingat, memproduksi perilaku (mencoba meniru sesuai dengan kemampuan fisik), kemudian menjadikan kebiasaan. Kebiasaan atau alasan untuk memperlihatkan perilaku tersebut akan terjadi bila ada penguatan perilaku (reinforcement). Penguatan perilaku dapat berupa imbalan (reward), atau hukuman (punishment). Penguatan perilaku juga dapat terjadi bila ada semacam janji-janji yang menyenangkan (imagined incentives) dan adanya vicarious (mengamati dan selalu teringat pada model yang menjadi idolanya) (Crain, 2000:199). Dalam berbagai progam pelatihan, peserta pelatihan akan belajar tentang suatu perilaku baru dan belajar mencobanya. Dalam pelatihan tersebut, peserta akan mendapat penjelasan tentang asal mula suatu perilaku baru, manfaat perilaku baru, berbagai kiat untuk menerapkan perilaku baru tanpa ada gejolak yang berarti baik dari individu itu sendiri maupun dari lingkungan sosialnya.

Penjelasan tentang suatu perilaku baru dalam pelatihan itu penting karena dalam situasi pelatihan, peserta didorong untuk melakukan suatu perubahan perilaku. Perilaku baru dalam hal kepemimpinan, misalnya, ternyata juga harus dilatih. Hal ini karena kepemimpinan bukan berasal dari keturunan atau kharisma, tetapi lebih kepada hasil latihan. Latihan itu akan membentuk karakter seseorang menjadi tangguh dan perilakunya menjadi suri tauldan bagi anak buahnya. 


\section{PELATIHAN KEPEMIMPINAN}

Apa saja pelatihan yang dapat membangkitkan dan mengembangkan kemampuan seseorang sehingga ia menjadi pemimpin yang tangguh? Pelatihan kepemimpinan dalam tulisan ini menggunakan teori belajar sosial (social learning theory) yang dikemukakan oleh Bandura (1977:1). Ada tiga alasan tentang penggunaan teori belajar sosial sebagai landasan bagi program pelatihan kepemimpinan (Allen, 2007:35). Alasan pertama, teori belajar sosial bersifat konstektual yaitu segala sesuatu (termasuk gaya suatu kepemimpinan) hanya dapat berjalan dengan baik pada suatu situasi tetapi tidak berjalan dengan baik pada situasi lainnya. Hal ini karena manusia (karyawan) pada hakekatnya adalah produk dari suatu lingkungan, sehingga manusia belajar dari lingkungannya (organisasinya) tentang segala sesuatu yang dapat diterima atau yang ditolak. Misalnya gaya kepemimpinan otoriter sangat sesuai untuk situasi gawat darurat tetapi tidak sesuai untuk situasi informal. Oleh karena itu pelatihan kepemimpinan seharusnya dapat memberikan kesempatan bagi para peserta untuk memahami situasisituasi apa saja yang sesuai untuk suatu gaya kepemimpinan.

Alasan kedua tentang pentingnya teori belajar sosial dalam pelatihan kepemimpinan adalah teori sosial belajar sangat menekankan pentingnya kesesuaian antara perkembangan kepemimpinan dengan kebudayaan yang menjadi latar belakangnya. Sistem penggajian, sebaliknya, justru lebih menekankan pentingnya faktor prestasi individu daripada faktor kebudayaan (lingkungan). Sebagai ilustrasi, karyawan yang sangat peduli dengan prestasinya padahal lingkungan sosialnya lebih mementingkan kolektivitas yang kurang memperhatikan prestasi individual, akan mendapatkan semacam sanksi sosial. Karyawan yang menonjol kerajinannya itu akan diasingkan karena berbeda dengan mayoritas rekan-rekan kerjanya. Adanya pelatihan kepemimpinan akan mendorong peserta untuk menghargai perbedaan-perbedaan yang ada di lingkungan kerjanya.

Alasan ketiga tentang pentingnya teori belajar sosial dalam pelatihan kepemimpinan berkaitan dengan keberadaan pemimpin sebagai model perilaku. Dalam melaksanakan tugasnya pemimpin tentu menginginkan semua instruksinya dipatuhi oleh anak buahnya. Kepatuhan anak buah akan muncul apabila pemimpin mampu menunjukkan perilaku yang patut menjadi suri tauladan. Hal ini karena anak buah akan selalu mengamatamati semua perilaku pemimpinnya. Dalam pelatihan kepemimpinan, peserta didorong untuk berani menjadi model yang perilakunya dihargai oleh lingkungan organisasinya. Peserta juga didorong untuk selalu konsisten dalam berperilaku.

Pertanyaan yang sering muncul dalam pelatihan kepemimpinan adalah seberapa efektifkah penerapan hasil pelatihan itu dalam kehidupan sehari-hari di organisasi (lingkungan kerja)? Secara ideal memang semua materi pelatihan kepemimpinan yang telah diberikan akan diterapkan 
secara konsisten di lingkungan kerjanya. Penerapan hasil pelatihan dalam kehidupana nyata memang menajdi tahap paling penting dalam perkembangankepemimpinanseseorang.Semakin pelatihankepemimpinan mirip dengan kenyataan di lingkungan kerja, semakin mudah bagi peserta untuk menerapkan hasil pelatihan.

Selain kemiripan situasi dengan kenyataan sehari-hari, efektivitas penerapan hasil pelatihan kepemimpinan dalam pelaksanaan tugas di organisasi juga bergantung pada empat hal yaitu perkembangan personal, pemahaman konsep kepempinan, adanya umpan balik, dan pengembangan ketrampilan (Jay Conger dalam Allen, 2007:35). Perkembangan personal berdasarkan asumsi bahwa seorang pemimpin yang baik hendaknya mempunyai mimpi dan bakat personal, serta berkeinginan keras untuk mewujudkannya dalam perilaku yang nyata. Jadi dalam pelatihan kepemimpinan, peserta akan didorong untuk mempunyai mimpi tentang sosok pemimpin ideal. Peserta juga didorong untuk membuat strategi agar mimpi-mimpi itu menjadi kenyataan dalam waktu yang tidak terlalu lama.

Hal kedua yang menurut Jay Conger penting dalam menerapkan hasil pelatihan kepemimpinan dalam organisasi adalah pemahaman tentang konsep kepemimpinan. Dalam pelatihan kepemimpinan, peserta akan mendapatkanberbagaiteoritentangseluk-belukkepemimpinan.Pemahaman teoritis ini penting untuk memperluas cakrawala pemimpin, dan juga sebagai petunjuk baginya bila ia harus memimpin dalam berbagai situasi yang berbeda-beda. Hal ketiga yang penting menurut Jay Conger adalah umpan balik. Dalam pelatihan kepemimpinan, peserta akan mendapatkan umpan balik tentang perilaku memimpinnya. Adanya umpan balik dalam program pelatihan kepemimpinan merupakan kesempatan bagi peserta untuk memperbaiki strategi kepemimpinan yang telah dimilikinya.

Hal keempat yang penting dalam menerapkan hasil pelatihan yaitu pengembangan ketrampilan. Menurut Jay Conger (dalam Allen, 2007:35), pelatihan selama 4-5 hari telah cukup bagi peserta untuk memahami tentang ketrampilan dasar dalam kepemimpinan. Sayangnya, pelatihan selama itu tidak menjamin seseorang menjaid pemimpin yang baik. Masih diperlukan serangkaian program agar peserta pelatihan dapat menerapkan hasil pelatihan. Program itu antara lain monitoring atau pemantauan seseorang di tempat kerja. Program pemantauan ini dilakukan berdasarkan prinsipprinsip behaviorism yang menekankan pentingnya seseorang melakukan trial error (mencoba-coba suatu perilaku) kemudian diikuti dengan penguatan perilaku seperti imbalan dan hukuman. 


\section{SIMULASI PADA PELATIHAN KEPEMIMPINAN}

Hampir pada setiap pelatihan, fasilitator selalu berusaha untuk membangkitkan minat peserta dalam memahami materi pelatihan. Simulasi yang diberikan pada hakekatnya adalah seperti 'jembatan' yang menjembatani antara situasi di tempat pelatihan dan situasi dalam kehidupan sehari-hari. Semakin mirip kedua situasi itu, maka semakin mudah pula bagi peserta untuk memahami materi pelatihan. Dalam tulisan ini, pelatihan kepemimpinan yang dibahas hanya sekitar 3 jam saja. Padahal secara ideal, pelatihan hendaknya dilakukan sekitar 4-5 hari. Oleh karena itu pelatihan yang akan dibahas dalam tulisan ini lebih kepada pemahaman tentang konsep kepemimpinan seperti yang dijelaskan oleh Jay Conger (dalam Allen, 2007). Jumlah peserta pelatihan adalah sekitar 20 - 30 orang.

Simulasi dalam pelatihankepemimpinanini yaitu fasilitatormenciptakan tiga macam situasi, dan pada masing-masing situasi diterapkan satu gaya kepemimpinan. Gaya kepemimpinan ada tiga macam yaitu demokratis, otoriter dan laissez-faire (serba boleh, permisif) (Riyono, 2001:15). Oleh karena itu peserta juga harus dibagi menjadi 3 kelompok. Agar gaya kepemimpinan itu dapat terwujud, maka peserta harus melakukan suatu tugas yang cukup rumit. Pihak yang menjadi pemimpin adalah salah satu peserta. Jadi dalam pelatihan ini peserta merasakan baik sebagai anak buah yang dipimpin dengan gaya kepemimpinan tertentu, maupun sebagai pemimpin yang memerankan gaya kepemimpinan tertentu.

Apa saja tugas yang harus dilakukan para anak buah itu? Mereka harus membangun sebuah jembatan dari bahan sedotan plastik (3 bungkus) dalam waktu 30 menit. Selain sedotan plastik, bahan lain yang dibutuhkan adalah jarum dekor (3 bungkus). Pertanyaan yang sering muncul dalam pengerjaan tugas adalah, mengapa peserta harus membangun sebuah jembatan? Apakah boleh peserta membangun suatu bangunan sesuka hati? Peserta harus membangun jembatan karena bangunan itu cukup rumit pengerjaannya, membutuhkan koordinasi kerja yang cermat antar anggota kelompok, dan membutuhkan perencanaan yang teliti. Dalam dunia nyata, jembatan dapat dibangun dengan menggunakan bambu dan paku. Dalam simulasi ini, sedotan plastik berfungsi sebagai bambu, dan jarum dekor berfungsi sebagai paku yang menghubungkan antara satu bambu dengan bambu lainnya.

Apa saja urut-urutan langkah simulasi dalam pelatihan kepemimpinan ini? Langkah pertama adalah fasilitator meminta 3 orang relawan untuk maju. Masing-masing relawan diminta untuk memerankan gaya kepemimpinan yaitu otoriter, demokratis, dan laissez-faire. Peserta lainnya kemudian dibagi menjadi 3 kelompok. Ada banyak cara pembagian kelompok, namun cara yang paling sering digunakan yaitu meminta peserta secara beurutan untuk berhitung 1 sampai dengan 3. Para peserta 
yang menghitung angka 1 menjadi kelompok yang pemimpinnya bergaya otoriter. Para peserta yang menghitung angka 2 menjadi kelompok yang pemimpinnya bergaya demokratis. Para peserta yang menghitung angka 3 menjadi kelompok yang pemimpinnya bergaya laissez-faire. Sebagai catatan, pada saat pembagian kelompok para peserta tersebut sama sekali tidak mengetahui gaya kepemimpinan dari pemimpin kelompoknya.

Langkah selanjutnya adalah anak buah membangun sebuah jembatan atas perintah atau pengarahan pemimpin, dalam waktu 30 menit. Peserta yang menjadi pemimpin otoriter diminta untuk memberi instruksi anak buahnya secara otoriter pula yaitu komunikasi hanya satu arah, pendapat anak buah tidak didengar, pemimpin sering memburu-buru waktu anak buah, dan pemimpin sering mencela pekerjaan anak buah. Pemimpin yang bergaya demokratis memberi instruksi dengan caa berembug, berdiskusi, mempertimbangan pendapat semua anggota, meminta komitmen anak buah untuk bekerja dengan cepat dan rapi, serta selalu bersedia membantu bila ada anggota yang merasa kesulitan mengerjakan tugasnya. Pemimpin yang bergaya laisez-faire, akan memberikan tugas pada anak buahnya dengan cara membiarkan anak buah berpikir sendiri, tanpa tuntunan, semua penfdapat anak buah hanya ditampung saja tanpa diberi komentar. Pendeknya semua kendali pengerjaan tugas ada pada anak buah, bukan pada pemimpin. Pada saat pengerjaan tugas ini, fasilitator hendaknya mencatat tentang kerjasama antar anggota pada semua kelompok dan proses pengerjaan tugas membangun jembatan.

Setelah waktu yang ditentukan habis, maka peserta diminta untuk memajang hasil karya kelompokknya di depan ruangan pelatihan. Sisa sedotan plastik juga diminta untuk diletakkan di dekat jembatan. Selanjutnya fasilitator meminta persetujuan peserta tentang indikator penilaian. Indikator itu antara lain berupa kemenarikan bangunan jembatan, kerapatan bagian tengah jembatan tempat untuk berjalan, dan jumlah sisa sedotan plastik. Sisa sedotan plastik yang terlalu banyak jumlahnya mencerminkan para peserta kurang mampu mendayagunakan bahanbahan dalam pembangunan jembatan, sehingga jembatan yang dihasilkan bisanya cenderung tidak menarik. Penilaian dilakukan untuk masingmasing indikator dengan skala penilaian 1-7, nilai satu menunjukkan tidak menarik dan nilai 7 menunjukkan sangat menarik. Berdasarkan indikator tersebut, maka dapat ditentukan nilai total pada masing-masing jembatan.

Setelah penilaian, fasilitator kemudian meminta komentar dari peserta yang hasil karyanya mendapat nilai paling tinggi. Hal-hal yang ditanyakan oleh fasilitator antara lain:

- Faktor apa saja yang menyebabkan tugas yang dilakukannya mendapat nilai tertinggi. 
- Apakah ada anggota kelompok yang perannya sedikit? Apakah ada anggota kelompok yang perannya dominan? Mengapa ada perbedaan intensitas partisipasi anggota?

- Apakah ada pembagian tugas pada para anggota (misal: bagian perencanaan, bagian merakit dasar jembatan, bagian merakit dinding jembatan, bagian distribusi bahan bangunan).

- Gaya kepemimpinan apa yang dirasakan oleh anggota kelompok? Apa indikatornya?

- Apakah pemimpin mendukung tugas kelompok?

- Apakah ada hubungannya antara gaya kepemimpinan yang dirasakan dengan kesuksesan menjalankan tugas?

- Apakah gaya kepemimpinan yang dirasakan anggota sama dengan gaya kepimpinan yang diinstruksikan oleh fasilitator pada pemimpin (misal pemimpin pada kelompok 1 diinstruksikan untuk bergaya otoriter, namun pada kenyataannya ia bergaya demokratis ketika memimpin anak buahnya dalam menjalankan tugasnya)? Mengapa terjadi ketidaksesuaian tersebut?

Kelompok yang mendapat nilai paling rendah juga mendapat kesempatan untuk menjawab semua pertanyaan yang sama dari fasilitator. Kelompok yang nilainya berada di tengah juga menjawab pertanyaan yang sama dari fasilitator. Langkah selanjutnya adalah diskusi, dan semua anggota kelompok diberi tugas untuk menjawab pertanyaan sebagai berikut:

- Apakah ada hubungan antara gaya kepemimpinan yang dirasakan dengan penerapan kerja pada kehidupan sehari-hari?

- Gaya kepemimpinan apa saja yang paling sesuai untuk mengerjakan suatu tugas dengan berbagai pertimbangan antara lain: waktu pengerjaan tugas (lama atau sebentar), tingkat kesulitan tugas, tingkat kegawatan tugas, keberadaan pakar sebagai salah satu anggota kelompok, tingkat heterogenitas anggota kelompok (umur, pendidikan, etnis, tingkat sosial ekonomi, agama, gender, dan ideologi).

- Apakah mungkin suatu organisasi dapat sukses meskipun tidak ada pemimpin? Pada situasi apa kehadiran pemimpin tidak diperlukan? Misalnya pada situasi yang mana meskipun tanpa komando pemimpin ternyata semua anggota kelompok sudah mengetahui deskripsi kerjanya dan bersedia mengerjakannya dengan tuntas, semua anggota kelompok bersedia membantu teman-temannya yang merasa kesulitan mengerjakan tugas, semua anggota mau dan mampu berkomunikasi dengan baik, dan semua anggota sudah terbiasa bekerja secara mandiri.

- Apakah yang harus dilakukan oleh anggota ketika mereka harus mengerjakan suatu tugas yang sangat penting (menyangkut hajat hidup orang banyak) namun ternyata pemimpinnya bergaya laissez-faire? 
Haruskah ada pemimpin bayangan? Apa saja konsekuensi bagi pemimpin bayangan terhadap pembagian reward (imbalan) apabila tugas sukses dilaksanakan? Juga sebaliknya apa yang terjadi dengan pemimpin bayangan apabila tugas gagal dilaksanakan sehingga kelompok terpaksa menanggung sanksi?

- Apakah yang harus dilakukan oleh anggota ketika mereka harus mengerjakan tugas penting dan harus segera dilaksanakan, namun pemimpinnya bergaya demokratis (meminta pendapat anggota secara rinci sehingga waktu pengerjaan tugas hampir habis)?

- Apakah yang harus dilakukan anggota ketika pemimpin yang dihadapi otoriter, dan sikap otoriter itu berkaitan dengan rasa rendah diri karena tingkat pendidikannya lebih rendah daripada pendidikan rata-rata anak buahnya?

\section{KESIMPULAN}

Pelatihan kepemimpinan ini sebenarnya tidak hanya memberi informasi kepada peserta tentang kepemimpinan saja, tetapi juga tentang bagaimana menjadi anak buah yang berguna bagi kemajuan organisasinya. Sesuai dengan prinsip social learning theory, peserta pelatihan mendapat kesempatan untuk mengamati semua perilaku dengan gaya kepemimpinan yang berbeda-beda, juga berbagai respon yang muncul dari sesama peserta. Hasil pengamatan yang paling menarik perhatiannya akan diingat-ingat, dan ia kemudian akan mencoba meniru perilaku yang menarik itu ketika ia mendapat kesempatan yang sesuai (menjadi pemimpin atau anak buah). Perilaku yang dicobanya itu kemudian akan menjadi kebiasaan ketika ia mendapatkan penguatan perilaku yang sesuai untuknya.

\section{DAFTAR PUSTAKA}

Allen, Scott J., 2007, Adult learning theory and leadership development. Kravis Leadership Institute. Leadership Review, 7, Spring, 26-37.

Bandura, Albert, 1977, Social Learning Theory. Diakses pada 24 Oktober 2012 dari http://www.instructionaldesign.org/theories/social-learning.html

Bussey, Kay dan Albert Bandura, 1999, Social cognitive theory of gender development and differentiation. Psychological Review, 106, 676-713.

Covey, Stephen R., 1997, Principle Centered Leadership. Jakarta: Bina Rupa Aksara.

Crain, William, 2000. Theories of Development: Concepts and Applications. 4th ed. New Jersey: Prentice Hall. 
Riyono, Bagus, 2001, Isu-isu Kontemporer dalam Psikologi Industri dan Organisasi. Yogyakarta: Unit Publikasi Fakultas Psikologi UGM

TimAndriwongso, 2012, Good Speech dari Dahlan Iskan. Diakses pada 7 September 2012 dari: http://www.andriewongso.com/awartikel-4755AW_Corner_Good_Speech_dari_Dahlan_Iskan 